Jurnal Lakon, 8 (2) 2019

(70-77)

\title{
THE STUDY OF INTERTEXTUALITY ON NOVEL ENTITLED A VERY YUPPY WEDDING AND DIVORTIARE BY IKA NATASSA
}

Kajian Intertektualitas pada Novel A Very Yuppy Wedding dan Divortiare Karya Ika Natassa

\section{ZAHRIA FARLYDIA FARIKHIN}

\author{
Program Studi Magister Kajian Sastra dan Budaya \\ Fakultas Ilmu Budaya Universitas Airlangga \\ Jl. Dharmawangsa Dalam Selatan, Surabaya 60286 \\ e-mail: zahria.farlydia.farikhin-2018@fib.unair.ac.id
}

\begin{abstract}
This research aimed to describe intertextual in the novel A Very Yuppy Wedding and Divortiare by Ika Natassa. This research used a descriptive qualitative approach in the form of structural. The result of the data analysis is that theme has similarity. The themes of these novels are love, friendship, and family. Figure and characterization in the novels has less different, the figures describe as a work hard figure not only for the job but also on their relationship. In both of the novel, both of the main characters are women and use the first person as the point of view. Whereas the plot of the novels has different, that is novel Divortiare has a flash-back plot and A Verry Yuppy Wedding has a progressive plot. Both of the novel have differences in the story but have the same happy ending. The background of the stories are not different. Ika Natassa takes both of the settings in Jakarta. The conclusion is both of the novels have no significant differences.
\end{abstract}

Keywords: A Very Yuppy Wedding, Divortiare, Intertextual Research

Abstrak: Penelitian ini bertujuan untuk mendeskripsikan intertektekstualitas dalam novel A Very Yuppy Wedding dan Divortiare karya Ika Natassa. Penelitian ini menggunakan metode deskriptif kualitatif dengan pendekatan struktural. Hasil analisis data menunjukkan adanya kesamaan tema dari dua novel ini. Tema-tema yang ditemukan adalah cinta, persahabatan, dan keluarga. Tokoh dan penokohan di dalam dua novel ini memiliki sedikit perbedaan, mereka digambarkan sebagai sosok yang bekerja keras tidak hanya dalam pekerjaan tetapi juga dalam hubungan. Karakter utama dari masing-masing novel adalah wanita dan semuanya menggunakan orang pertama sebagai sudut pandang. Padahal, alur ceritanya berbeda, yaitu novel Divortiare memiliki alur kilas balik dan A Verry Yuppy Wedding memiliki alur progresif. Kedua novel memiliki perbedaan dalam cerita tetapi memiliki akhir yang sama, yaitu akhir bahagia. Latar belakang cerita tidak berbeda. Ika Natassa mengambil latar belakang cerita di Jakarta. Kesimpulan dari penelitian ini adalah novel A Very Yuppy Wedding dan Divortiare tidak memiliki perbedaan yang signifikan.

Kata-kata Kunci: A Very Yuppy Wedding, Divortiare, Intertextual Research, Kajian Intertektualitas

\section{INTRODUCTION}

Intertextual is a relationship that is contained in an essay text where the text is the result of a transformation from the text of the previous essay that is used as a reference. The purpose of this intertextual study is to compare certain aspects of literary works that have appeared before in literary works thereafter. Through this

Jurnal Lakon: Kajian Sastra dan Budaya

e-ISSN: 2527-4899; p-ISSN 2252-8954 
comparison, the researcher knows the relationship that exists between literary works, looks at the creativity of the writer and finds historical elements in every literary work.

Readers or connoisseurs of literature often unconsciously and consciously also make comparisons of existing literary works. This because the novels are literary works that are very close to society. Besides, the novel is also a literary work that allows having differences and similarities between one novel and another. Therefore, intertextual studies are made to examine differences and similarities in literary work.

The researched and compared novels in this study are A Very Yuppy Wedding and Divortiare novels by Ika Natassa. The two novels were chosen because so few other researchers were interested in making these novels the object of their research. Therefore the researcher conducted this intertextuality research by making both of them the object of research. As is known, the novel entitled A Very Yuppy Wedding is the first work from Ika Natassa, which is about a woman named Andrea, a young banker who is currently pursuing a career in one of the largest banks in Indonesia. But at the age of 29 years, Andrea might have to change her priorities because now Adjie will marry her soon.

Ika Natassa has published several works that are all liked by the public and attracted the interest of several researchers to discuss their works. Likewise with Divortiare, which is also written by Ika Natassa. This novel is Ika Natassa's second novel after A Very Yuppy Wedding. The Ika Natassa books have recently become very popular with the public. Even some of them have been appointed to the big screen with an audience of thousands of people.

This study focused on four problems, namely the determination of the hypogram and the text of the transformation in the elements of the theme, character, and characterization, plot, and setting found in the novel A Very Yuppy Wedding and Divortiare. By describing the four intrinsic elements of the two novels, it is expected that the reader can see the comparison of the two and determine which works are transformational texts and hypogram texts.

The theory used in this study is first, the novel means a work of prose fiction that is quite long, not too long, but also not too short (Nurgiyantoro, 1995: 9). Plus the theories from Lukacs and Girard, Goldman (in Faruk, 1994: 29) define novels as stories about a search that is degraded by authentic values carried out by a problematic hero in a world that is also degraded. Novel has intrinsic and extrinsic building elements. Intrinsic namely the theme, character, characterization, background, plot, conflict, climax, point of view, language style, and mandate. Extrinsic, namely the author's biography, author's psychology and readers, author's social conditions (economics, politics, social, culture, and religion), and the view of life in the environment of the author (Nurgiyantoro, 1995).

Second, the study is to do an act of studying, investigating, or researching literary works. To study the elements of literature, especially the work of fiction, is always accompanied by analytical work (Nurgiyantoro, 1995: 30). The intertextuality study is intended as a study of several texts that are thought to have a certain relationship, such as the 
relationship of intrinsic elements such as ideas, ideas, events, plots, characterizations, language styles, and others among the texts studied (Nurgiyantoro, 1995: 50). Teeuw (in Nurgiyantoro, 1995: 52) says that a literary work can be a hypogram for other literature even though it is not explicit. The form of a hypogram may be a continuation of a convention, something that has existed, aberration and rebellion of the convention, the twisting of the essence, and the mandate of the previous text. Intertext is a methodological space in which the reader can hold free associations with previous reading experiences that make it possible to provide wealth for the text being read (Ratna, 2008: 175). Practically intertext activities occur in two ways, namely: a) reading two or more texts side by side at the same time, b) only reading a text but against the background of other texts that have been previously read (Ratna, 2008: 174).

\section{METHOD}

The method used is descriptive. The descriptive method is a method by analyzing and deciphering data in the form of words or sentences instead of numbers. The form of this research is qualitative research. Qualitative methods are research procedures that produce descriptive data in the form of written or oral words from people and observable behavior (Bogdan and Taylor in Moleong, 2011: 4). The approach used is a structural approach which is a structural analysis of literature, in this case, is fiction, can be done by identifying, studying, and describing functions and relationships between the intrinsic elements of the relevant fiction (Nurgiyantoro, 1995: 37). The data source in this study is the novel entitled $A$ Very Yuppy Wedding and Divortiare. The data to be used in this study are quotations, words, sentences, or texts from A Very Yuppy Wedding and Divortiare novels.

The data collection technique chosen is a library technique, which is done by reading novels or research data sources which then each thing in the form of quotations as research data is documented. The data collection tool used is the researcher himself. The researcher becomes the main instrument or tool that serves as a planner, executor, data collector, data interpreter, and reporter of research results.

In addition to the researchers themselves, a notecard is also needed which will help in recording the results of the data that have been analyzed. The data analysis technique chosen is qualitative, this refers to data that is written or in writing, not numbers. And checking the validity of the data done is first, referential adequacy, understanding and reviewing the sources of various libraries that are relevant to the problem. Second, namely the persistence of observation to gain a deep understanding of the data analyzed. The researcher analyzed by reading the quotes and novel texts repeatedly diligently and thoroughly, determining quotations related and having intertextual elements, analyzing the data according to the chosen problem, and drawing conclusions from the research.

\section{DISCUSSION}

This study discusses four problems, namely the hypogram and transformation text on the theme, character, and characterization, plot, point of view, and the background in the novel A Very Yuppy Wedding and Divortiare. Through the results of this analysis, intertextuality can

Jurnal Lakon: Kajian Sastra dan Budaya 
be described between the two novels. The results of the first analysis are about themes. The themes of the two novels are love, friendship, and family. Love which is meant here is a woman to a man which in $\mathrm{A}$ Very Yuppy Wedding novel is Andrea's love for Adjie, and vice versa. In Divortiare's novel is Alexandra's love for Beno, and vice versa. Then in addition to the theme of love, there are also two themes implicit in these two novels, namely friendship and family.

The second analysis is about characters and characterizations. The main female characters in these two novels, Andrea and Alexandra, both have jobs as bankers who are busy and have travel sickness if they are visiting a client site with a long trip. This can be seen from the following quote:

"Apa yang salah dengan gambaran ini? Sejujurnya sama sekali tidak ada. Kecuali fakta bahwa aku menderita motion sickness-terkadang aku lebih suka menyebutnya motion sucknessdan sudah setengah jam aku mencoba menahan diri untuk tidak muntah." (A Very Yuppy Wedding, 2007:1)

The hypogram with the following quote from Alexandra:

"Aku memejamkan mata. Kepalaku rasanya mau pecah, dan keringat dingin mulai menetes di dahiku. Bukannya aku punya fobia terbang (sedikit sih, apalagi dengan sejarah penerbangan Indonesia belakangan ini), tapi mungkin hari ini kondisi tubuhku sedang kurang sehat. Sejak tadi siang saat aku menginjakkan kaki di pesawat, duduk, dan mengencangkan safety belt, all I wanted to do was throw up. And possibly pass out." (Divortiare, 2008:1).
Then, the two main characters in both novels turned out to have two close friends who really cared about him.

In A Very Yuppy Wedding Novel, Andrea is friends with Tania and Firman who have the same traits as Alexandra's friends in Divortiare's novels Wina and Ryan. Tania and Wina are both portrayed as women who care deeply about their friends Andrea and Wina. Tania's concern can be seen from the following quote:

"Andrea, lo dimana? Adjie udah kayak orang gila nyariin lo! Pake ganti-ganti nomor, lagi!" (A Very Yuppy Wedding, 2007:262).

The quote is Tania's words when she calls Andrea who runs away at night even though tomorrow is her wedding day with Adjie. Whereas Wina's concern can be seen from the following quote:

"Alexandra, I hate to sound like cheesy romantic novels, but just because he hurt you, doesn't mean it's gonna happen again when you open your heart again to the next guy, right?" (Divortiare, 2008:79).

Wina's words above happened because Wina still saw the tattoo bearing with the name of Beno on the chest of his friend, Alexandra, who was now divorced from Beno. After the divorce, Alexandra still did not "eliminate" her ex-husband's name on her left chest. It's not a nominal question of money that must be poured out to do a laser, but more because for Alexandra the tattoo is a reminder that he was once happy. Hearing such reasons makes Wina say as quoted above. Wina wants Alexandra to be happy without Beno. 
The third analysis is about the plot. The flow of the two novels is different. If $A$ Very Yuppy Wedding has an advanced flow, Divortiare has a mixed flow.

"Okay, friends don't kiss each other passionately on the lips. Adjie dan aku memang bukan sekadar teman. Tapi karena peraturan bank yang melarang pegawainya berhubungan dan menikah, aku dan Adjie memang harus merahasiakan hubungan kami, paling tidak di kantor." (A Very Yuppy Wedding, 2007:12).

While in Novel Divortiare:

"I should have known that bankers and doctors shouldn't get married because they live in totally different time zones. Sudah begitu, ada lagi peraturam aneh yang mengharamkan sesama bankir di bank yang sama menikah." (Divortiare, 2008:84).

From these two quotes, it can be seen that both of them are in the same condition, they are not allowed to marry fellow bankers in the same bank. However, Andrea in A Very Yuppy Wedding novel explained that at the beginning of the story, while Alexandra told it when she was telling her past times with Beno.

Alexandra tells how she and Beno should not get married because doctors and bankers have different "time zones". Alexandra told this when Beno after calling him. Alexandra told her marriage with Beno, the conversation with Beno was on the phone for no more than 2 minutes because Beno was always a patient and had to be operated immediately. After Beno hung up, Alexandra thought that he should not marry a doctor. But at that time he also thought that there were regulations in the office that did not allow him to marry fellow bankers at the same bank.

The fourth analysis is the point of view or point of view. The point of view used in telling the two novels is the perspective of the first person. This can be seen from the following quote:

"Dan mohon maaf jika aku sering menggunakan bahasa inggris. Semua temanku mengakui Bahasa Indonesiaku kacau abis." (A Very Yuppy Wedding, 2007:12)

"Saat akhirnya aku berjalan menenteng carry-on luggage-ku menuju terminal kedatanga, rasanya aku sudah mau pingsan, dan ingin segera merebahkan tubuhku di kasur kamarku yang empuk." (Divortiare, 2008:12).

From the quotation above, it can be seen that the point of view used in these two novels is the perspective of the first person because both of them use the word "I" to explain every action that they will take and the feelings they feel.

The fifth analysis is the background. The location of the two novels is Jakarta, the capital city of Indonesia. This can be seen from the following quote:

"Sabtu siang ini aku dan Adjie memilih makan di Crystal Jade di Plaza Indonesia, janjian bareng Tania dan Ical." (A Very Yuppy Wedding, 2007:168) dan "Aku tadi mau minta tolong sama kamu, aku mau pinjam kunci rumah kita yang di Kebagusan. Kunciku hilang." (Divortiare, 2008:144).

From the above quotation, it can be seen that the location of the story in the two

Jurnal Lakon: Kajian Sastra dan Budaya e-ISSN: 2527-4899; p-ISSN 2252-8954 
novels is Jakarta. Plaza Indonesia and Kebagusan, are two popular names in Jakarta. In addition, dialogues between leaders who use the words "lo" (you) and "gue" (me) have indicated a Jakarta centric. Because where else in Indonesia, which in everyday language will be full of using the words "lo" (you) and "gue" (me) in each conversation.

After the five analyzes above, it is time for researchers to arrive at the final analysis, which is about the similarities that exist at the end of the story in both novels and also the differences in the contents of the story. A Very Yuppy Wedding novel tells the story of Andrea and Adjie who are both a banker in the same bank. Both of them have been in love for one year, even though they know that the office where they work does not allow them to date. All their efforts were done but all that had to be revealed was when Andrea was introduced by Adjie's mother to one of her friends named Karen. Which is where Karen is the boss of Andrea and Adjie in the office. After that happens, Andrea and Adjie are called by Mrs. Karen to face and tell about their relationship and decide who will stay and move. Finally, Andrea chose to move and work in another bank, while Adjie settled in his old office. From here comes the problems that plague both. Because it turns out, Andrea is one office with her ex-lover, Radit. Radit who was still friendly to Andrea turned out to have bad intentions. He approached Andrea again with the aim that Andrea would not marry Adjie.

While Andrea burned jealously every time Adjie went to see work outside his office with a woman named Ajeng. These things made Andrea doubtful so that the night before his wedding day, he ran away from home and went to a place accompanied by Radit. Andrea's thoughts about Adjie's feelings towards him continued to fill his mind until he turned out to be wrong to kiss someone he thought Adjie. Apparently, it was Radit. Andrea immediately rushed away but was detained by Radit, and it turned out that the incident was witnessed by Adjie himself. Adjie hits Radit and takes Andrea away. There Adjie said that he would free Andrea to make choices about tomorrow. Whether the marriage will continue or not. There Andrea realized that he loved Adjie and could not part with him. Until finally tomorrow's wedding continued and then they moved to a bigger apartment. That's where their lives run happily, and perfectly.

Divortiare's novel begins with the story of Alexandra who fainted after a work trip from outside her city. Before fainting, he called Beno, who was a doctor and also his ex-husband. After divorce, Beno is Alexandra's personal doctor. Despite having divorced and having their lives, Beno and Alexandra often meet in several unexpected places. Alexandra often accused Beno of following him, but even though this was not the case. The separation between them did not make Beno lose his concern for his exwife. Beno's good intention to help Alexandra was often made into a debate. Since divorcing Beno, Alexandra hasn't dated anyone. All he does is work and work. Until one day Alexandra's theme, Wina, told her to date again. This time Wina is looking for a candidate for her best friend. Until one day it turned out that the candidate intended by Wina was Denny, their college friend first. The meeting with Denny went smoothly until finally the two of them often spent time together until finally dating. Gradually their relationship went on, it turned out that Alexandra still remembered Beno and anything they had done. 
Starting from activities to vacation spots, all brought Alexandra as if she were still bound by her memories with Beno. Until one day at his home, while looking for a passport, Alexandra found a passport and all the stamps on the place of travel that he had visited with Beno. It was there that his heart was shaken, he said to Denny that their relationship could not continue and Denny immediately blamed it all for Beno. What Alexandra did not deny and acknowledge was making her and Denny separated. After his separation, Alexandra met Beno accidentally after visiting the hospital where Vienna gave birth to his daughter. There Beno asked about Denny's reply to Alexandra's question about Rani, the woman who was reportedly close to Beno. Alexandra is angry when mentioned about Denny and vice versa, Beno when mentioned about Rani. This novel ends with Beno's invitation to Alexandra, which is to eat their favorite fried rice which he then gives.

From the story above, it can be concluded that the two novels have different ends. If A Very Yuppy Wedding ends with happiness because Andrea and Adjie finally get married. Divortiare does not show a clear end to their story. Divortiare only shows that Beno and Alexandra can improve relations by starting with their favorite menu of fried rice food.

\section{CONCLUSION}

The results of the analysis and discussion of the data in this study indicate that A Very Yuppy wedding is having the hypogram on Divortiare. This can be seen in the results of the analysis carried out on five problems namely the theme, character and characterization, plot, point of view, and background.
In each analysis by Ika Natassa, the $A$ Very Yuppy Wedding novel shows an intertextual relationship with another Ika Natasaa novel entitled Divortiare. The intertextual relationship is very evident in the analysis of these problems. Both of them raise the same theme, namely love, family, and friendship. In the second analysis, there were also a number of additional figures who shared the characters and main characters of the two novels showing the same character with the background which was not much different. In the flow analysis, it began to appear that Divortiare novels experienced writing creations. A Very Yuppy Wedding novel selects the forward flow in the story and Divortiare chooses a backward or mixed flow. But, in the stages, it still looks A Very Yuppy Wedding is still on the program on Divortiare. And finally, in the background analysis. Both show similarities.

The two novels are set in Jakarta, apart from the dialogue between Jakartacentric figures, the novel also mentions famous places in Jakarta such as shopping centers and residential areas. In addition, differences also exist in the way the writer ends the story of the two novels. If the novel A Very Yuppy Wedding clearly gives the end of the story where Andrea and Adjie are married, while Divortiare's novel ends with Beno who invites Alexandra to eat their favorite fried rice.

\section{REFERENCES}

Faruk. (1994). Pengantar Sosiologi Sastra. Yogyakarta: Pustaka Pelajar.

Moleong, Lexy J. (2010). Metodologi Penelitian Kualitatif. Bandung: PT Remaja Rosdakarya.

Natassa, Ika. (2007). A Very Yuppy Wedding. Jakarta: Gramedia Pustaka Utama 
Natassa, Ika. (2008). Divortiare. Jakarta: Gramedia Pustaka Utama

Nurgiyantoro, Burhan. (1995). Teori Pengkajian Fiksi. Yogyakarta: Gajah Mada University Press.

Ratna, Nyoman Kutha. (2008). Teori, Metode, dan Teknik Penelitian Sastra. Yogyakarta: Pustaka Pelajar 